\title{
Learning English in Third Grade through Powtoon
}

\author{
Suprianti, G.A.P \\ English Language Education/ Faculty of Language and Art Ganesha University of Education, Singarja Indonesia \\ Email: gap.suprianti@undiksha.ac.id
}

Mahayanti, N. W. S. English Language Education/ Faculty of Language and Art Ganesha University of Education, Singarja Indonesia Email: mahayantisurya@yahoo.co.id

Suarjaya, P.A.A.G

English Language Education/ Faculty of Language and Art Ganesha University of Education, Singarja Indonesia Email: suarjayaputra@gmail.com

\section{A R T I C L E I N F O \\ Article history: \\ 1 Maret 2020 Received in revised form \\ 30 Maret 2020 \\ Accepted 11 April 2020 \\ Available online 15 \\ Mei 2020

\begin{tabular}{l}
\hline Kata Kunci: \\
Video Animasi PowToon, \\
Bahasa Ingris
\end{tabular} \\ Keywords: \\ PowToon, Animation Video, \\ Learn English}

\begin{abstract}
A B S T R A K
Saat ini, guru bahasa Inggris di sekolah dasar masih menggunakan media konvensional dalam mengajar bahasa Inggris. Berdasarkan fenomena tersebut, peneliti mengembangkan media dengan tujuan untuk mengembangkan video berbasis animasi Powtoon untuk mengajar siswa kelas tiga sekolah dasar.Data penelitian ini dikumpulkan melalui wawancara, analisis silabus, angket siswa, dan pencatatan dokumen. Model ADDIE oleh Romiszowski dikembangkan sebagai prosedur penelitian ini. Hasil penelitian menunjukkan bahwa video berbasis animasi PowToon dapat digunakan untuk mengajar bahasa Inggris untuk siswa kelas tiga sekolah dasar. Dari kuesioner siswa, ditemukan bahwa video animasi dapat menarik perhatian siswa dan juga memotivasi siswa selama proses belajar mengajar. Media dikategorikan sebagai media yang baik dengan melakukan rubrik penilaian ahli. Jadi, video berbasis animasi PowToon dapat digunakan sebagai alternative media pembelajaran bahasa inggris.
\end{abstract}

\begin{abstract}
A B S T R A C T
Nowadays, the English teachers in elementary school still use conventional media in teaching English. Based on the phenomena, the researcher developed a media with the aimed to develop Powtoon animation based-video for teaching third-grade students of elementary school. The data of this research were collected through interview, syllabus analysis, students' questionnaire, and document recording. ADDIE model by Romiszowski was developed as the procedure of this research. The result of this research was PowToon animation based-video can be used to teach English for third-grade students of elementary school. From the students' questionnaire, it found that the animation video could attract the students' attention and it also motivated the students during the teaching and learning process. The media was categorized as good media by conducting expert judgment rubric. So, PowToon animation-based video could be used as an alternative media in learning English.
\end{abstract}

\section{Introduction}

Learning English from an early age is a better way to develop young learners' ability. It is supported by theoretical of an expert in education (Piaget, 1973) who believes that the earlier children learn a foreign language or target language; young learners will have more time and opportunities in acquiring a high proficiency in learning the target language. According to (Baldauf, Kaplan, Kamwangamalu, \& Bryant, 2012) introducing English from an early age become a common way of doing in schooling in this era. It will affect the regulation of the government to make a standard for school in which the primary school should have an English program earlier. In Indonesia, most of the primary school started the English program from grade four, but there are some primary schools starts the English program from grade one. It depends on the regulation of the school.

Students in grade one is still considered as a young learner and teaching English to them from an early age is not easy. Simple's way needs to be used to deliver message or knowledge from teacher to young learners. Everything that can be used to deliver messages from deliverer to a receiver which can stimulate feelings, minds, cautions and students' interest called as media (Sadiman, 1986). There are lots of media and activities which can be implemented for teaching young learners. The basic thing which young learners need in learning English is how the interest in the learning process. A fun activity and media should be used to attract their comfort zone while learning English. Using conventional media can be an interesting way in teaching young learners, but in 
the era of technology, using some kinds of gadget such as a laptop, smartphone and computer are the most interesting activity doing by young learners which can meet the learners' need with the students' innate skills (Sarkar, Ford, \& Manzo, 2017). Therefore, using media such as technology is the way which teacher should use to teach young learners in this era.

One of the animation programs used for this study is PowToon (www.powtoon.com). It is web-based animation software which allows teachers to quickly and easily create animated presentations by combining objects, imported images or videos, provided music and user created voice-overs making the teaching- learning process more engaging and enjoyable for young learners. Powtoon presentations can be exported to other programs such as Youtube and PowerPoint that give the flexibility to share the interesting media. Powtoon is also user-friendly which allow the teacher to create and design whatever the teacher wants when it is still appropriate with what the students' need in the learning process. PowToon can be used to teach all the subject (Charbel \& Ismail, 2018); "it could be implemented in an English class to demonstrate knowledge of Romeo and Juliet from a student's perspective, and even in an industrial arts class by demonstrating welding techniques." PowToon paves the way to develop higher-order thinking skills like critical thinking, summarizing, and problem-solving, and those basic skills are the way to be a successful global citizen in the 21 st century. Research about the effect of Powtoon animation based-video for teaching English as foreign language (Charbel \& Ismail, 2018) also shown that Powtoon has a positive effect on the learners' level of engagement, comprehension and developing reading strategies.

Based on the phenomenon happened in an elementary school in Singaraja, the most school which has an English program from grade one does not use any ICT media for teaching students. From the preliminary observation at SDN 3 Banjar Jawa that was conducted on Wednesday 9th January 2019 with the third-grade students and interviewed with the headmaster of the school, it was found that ICT-based media already exist in the school but the teacher does not really familiar to use it. Actually, students in the third grade were familiar with the digital media; they already had their smartphone or laptop at home. Because of the teacher not really familiar using media such as video-based or electronic book in the teaching process, most of the students feel that learning using ICT-based media is not needed. But in reality, most of the students of third grade really interested in using digital media if there is an ICT based media for teaching them. If the teacher could go deeply to see a chance in developing students' ability, especially English, an animation-based video could be used as media to teach them. The headmaster also mentioned that if the researcher can make an ICT-based media for teaching English it will be more helpful for the teacher to teach students.

Therefore, by looking at the phenomenon happened in an elementary school in Singaraja. The researcher wants to develop animation based-video for teaching English of student's grade three of an elementary school in Singaraja.

\section{Method}

This research belongs to the research and development ADDIE model. ADDIE is the acronym of a system of instructional design, comprised of the following: Analyze Design, Development, Implementation, and Evaluation. The researcher conducted this research to develop a prototype product as supplementary media for third-grade students of an elementary school in Singaraja. To develop prototype media, there were only three steps such as analyze, design, and development done by the researcher as the procedures of this research. The goal of this research is to support the students by existence educational video based-animation media in which they can increase their knowledge both in and outside the classroom of school hours. Therefore, the researcher proposed using Powtoon animation based-video as media to improve students' ability in learning English. The development model used in this research is the ADDIE Model (Romiszowski, 1996). This model organized by steps of activity systematically and focuses on solving the problems which occur in the learning process especially the learning source problems such kind of media.

This research was conducted at SD Negeri 3 Banjar Jawa Singaraja. For the participants of this research were 30 students of the third grade of SDN 3 Banjar Jawa Singaraja and the teachers who taught English. Moreover, the third grade students of SD Negeri 3 Banjar Jawa Singaraja were chosen as the participants because the students in the third grade commonly have their hand-phone.

In the research, four methods of data collection that used such as interview, observation, questionnaire and document study. 1) Interview. The first method of collecting the data can be done in the form of interview. The aim is to know deep information from the respondents. There are two kinds of interview, namely structured interview and unstructured interview. Structured interview is the method where the researcher know about the information will be obtained. Thus, the researcher can make the outline of questions and prepare the alternative answer. While the unstructured was the opposite of the structured interview where the researcher do not know about the information will be obtain. Therefore, the researcher prepared the interview guide to remind what the important point asked to the informants and write down the information from the respondent. Furthermore, in this research, the researcher used the unstructured interview. In this method of data collection, the researcher got 
an information about the situation of the class when learning English, how the learning process goes run and condition of students in the class by asking the informant such as the teacher and the headmaster of the school. 2) Observation. The second method of data collection can be done in the form of observation. It is used for research on human behaviour, work processes, natural phenomenon, and a small number of observe-subjects. Observation can be divided into two kinds, namely participant observation and non-participant observation. Participant observation means that the observer is involved in the activity of students learning process. While non-participant observation is the observer is only observe the learning process in the class without include in the activity. In this research, the reseracher used participant observation. The researcher was pay attention and wanted to watch and contributed the entire event during the observation. In doing an observation, the researcher observed about the learning process goes run in the class, observe the students' attention while following the activity of the learning process which is the learning activity enthusiasm or not. Capture some situation also did by the researcher when doing observation in the class. 3) Questionnaire. The third method of data collection can be done in the form of questionnaire. The researcher gave set of written questions to respondents, in aiming to know exactly the answers from the respondents. It is also supported by Sekaran as cited in (Sugiyono, 2010), he mentioned that there are 10 principles that should be follow in writing the questionnaire, namely; the content and the purpose of the questions, the language use, the type and the form of the questions, the questions do not repeatedly appear, the questions do not lead to the certain answer, the questions are not about something that have been forgotten, the question is not too long, the order of the question is from the general to specific, the questionnaire should be valid and reliable, and the appearance of the questionnaire. By giving the questionnaire, the researcher collected a specific data of what the needs of the students, what is the problem of the students when following the learning process, and how they like about the activity happen in learning process. They chose some of options the use of ICT-based media. 4) Document Study. The last method of data collection is documents study. According to Sukmadinata (2010) document study is a method of data collection which is focused on collecting and analyzing the document. It can be in the form of written, picture or electronic document. This study used this method to get the data about the scope of material or topic from the syllabus and lesson plan for fifth grade students in the second semester which used as content that should be put in the media. The document study had done in two times. The first one the researcher did a syllabus analysis, and the second was the result of the document study compared with the result of the interview to make sure that the material is appropriate for the animation.

There are three procedures which were conducted in this research as follows. Analyze, the researcher conducted an interview. The interview has a purpose to know whether the teacher already good in involving the media in the teaching and learning process. And also the ability of the teacher in order to make the media. Then, conducting the document study. The document study has the purpose to know the scope of the study that is used to make the animation video. Next, distributing questionnaire. The questionnaire is distributed at the beginning of the study to collect the information related to the problem and needs of the development. Then, in the step of design, the researcher designing the material of the video. To design the framework of animation video before the development process begins. Next step is developed, the researcher developing the Powtoon animation based-video on the framework that already designed.

\section{Results and Discussion}

In developing media Powtoon animation based-video, there are several steps which were conducted by the researcher, those are:

\section{Analyze}

Analze in this step, the researcher collected the data from students' questionnaire. The questionnaire consists of fourteen question which asked about the students' opinion about learning English, how their teacher taught them in the English class, the use of media in the class, students' willingness to use smartphone or laptop in learning English, and the last is students' interest to watch and read if later on there is a visuals book or video. Overall, the students answered that they interest in learning English using such kind of media in the form of visuals book or video. (1) From the teacher's interview, the researcher asked some questions, the first question was about the teacher comprehension in using media when taught students. The teacher said she already provided with LCD in the school at each of the class and also she said she could operate laptop but not really expert. But she could have such kind of power point as media to taught English in the class. The second question was about the teacher readiness if the researcher tried to make such kind of ICT media. The teacher said that she would try to learn using media no matter the age already old she would learn how to use it. She also said that in the past there is a game in the form of $\mathrm{CD}$ but now it already broken and she could not use it again. Then the researcher tried to confirm again that the researcher would develop ICT media from first grade students, she said it really good. Also the researcher tried to explain about the ICT media such as Powtoon animation based-video, Camtasia and Story Jumper. For the last question, the researcher asked about the connection facilities to the internet about readiness of Wi-Fi connection in SD Negeri 3 Banjar Jawa Singaraja. The teacher said that in that 
school, the Wi-Fi connection already installed but its only use by the teachers in the teachers' room because the range signal of Wi-Fi was not really wide, and most of the students' class could not use this facility. (2) In syllabus analysis, the researcher collected the data about the number of the topic that developed into Powtoon animation based-video. While there are six topics which is relevant to develop into video, such as jobs, hobbies, names of days and activities, names of months and dates, time and activities on Sundays, and places in the house and activities in that place. All the topics in second semester were chosen as media of Powtoon animation basedvideo.

\section{Design}

Design, in this step, the researcher had done drafting of the media by collecting the picture used in the video. Then, conducting expert judgement by material experts. There were two experts of material development, and those were lectures of English Language Education. In rating the quality of media designed, the researcher used formula by Nurkancana and Sunartana (Mahayanti, 2017) and scoring rubric consists of 15 statements about the quality of the media.

Table 1. Formula Used in Rating the Material

\begin{tabular}{ll}
\hline Score & Criteria \\
\hline$X \geq \mathrm{M} i+1.5 S d i$ & Excellent \\
$\mathrm{M} i+0.5 S d i \leq X<\mathrm{M} i+1.5 S d i$ & Good \\
$\mathrm{M} i-0.5 S d i \leq X<\mathrm{M} i+0.5 S d i$ & Average \\
$\mathrm{M} i-1.5 S d i \leq X<\mathrm{M} i-0.5 S d i$ & Below Average \\
$X<\mathrm{M} i-1.5 S d i$ & Poor \\
\hline
\end{tabular}

Nurkancana and Sunartana in (Mahayanti, 2017)

In the rubric of expert material, there were two components which were divided into fifteen items. The maximum and minimum score for each question was 5 for maximum and 1 for minimum. The score of 5 represented very appropriate and the score of 1 represented very inappropriate. Therefore, total maximum score was 75 and total minimum score was 15 . However, the analysis of measuring quality of the media developed was describing bellow.

Table 2. The calculation in Rating the Material

\begin{tabular}{ll}
\hline Score & Criteria \\
\hline$X \geq 67.5$ & Excellent Material \\
$52.5 \leq X<67.5$ & Good Material \\
$37.5 \leq X<52.5$ & Average Material \\
$22.5 \leq X<37.5$ & Below Average Material \\
$X<22.5$ & Poor Material \\
\hline
\end{tabular}

Based on the result of expert judgement, it was found that total score of the first expert judge was 71. It was categorized as excellent media. Next, from the second judge, the media got score 72 . It was categorized as excellent media. Finally, from those two results of expert judgement rubric, the material could be categorized as 'excellent media'. There was some revision in the form of grammar, pictures, and dictions. After the researcher consulting the media with the supervisors, there is no revision in the aspect of pictures. But, there are some revision in the aspect of grammars, dictions and punctuations

\section{Developing}

In developing the media, the researcher made it in Powtoon web based-application. There are six topics are developed into Powtoon animation based-video such as jobs, hobbies, names of days and activities, names of months and dates, time and activities on Sundays, and places in the house and activities in that place. Then, conducting expert judgement by the media expert. The media developed can be seen in the Table 3 .

Table 3. The sample of Developed Powtoon animation based-video 


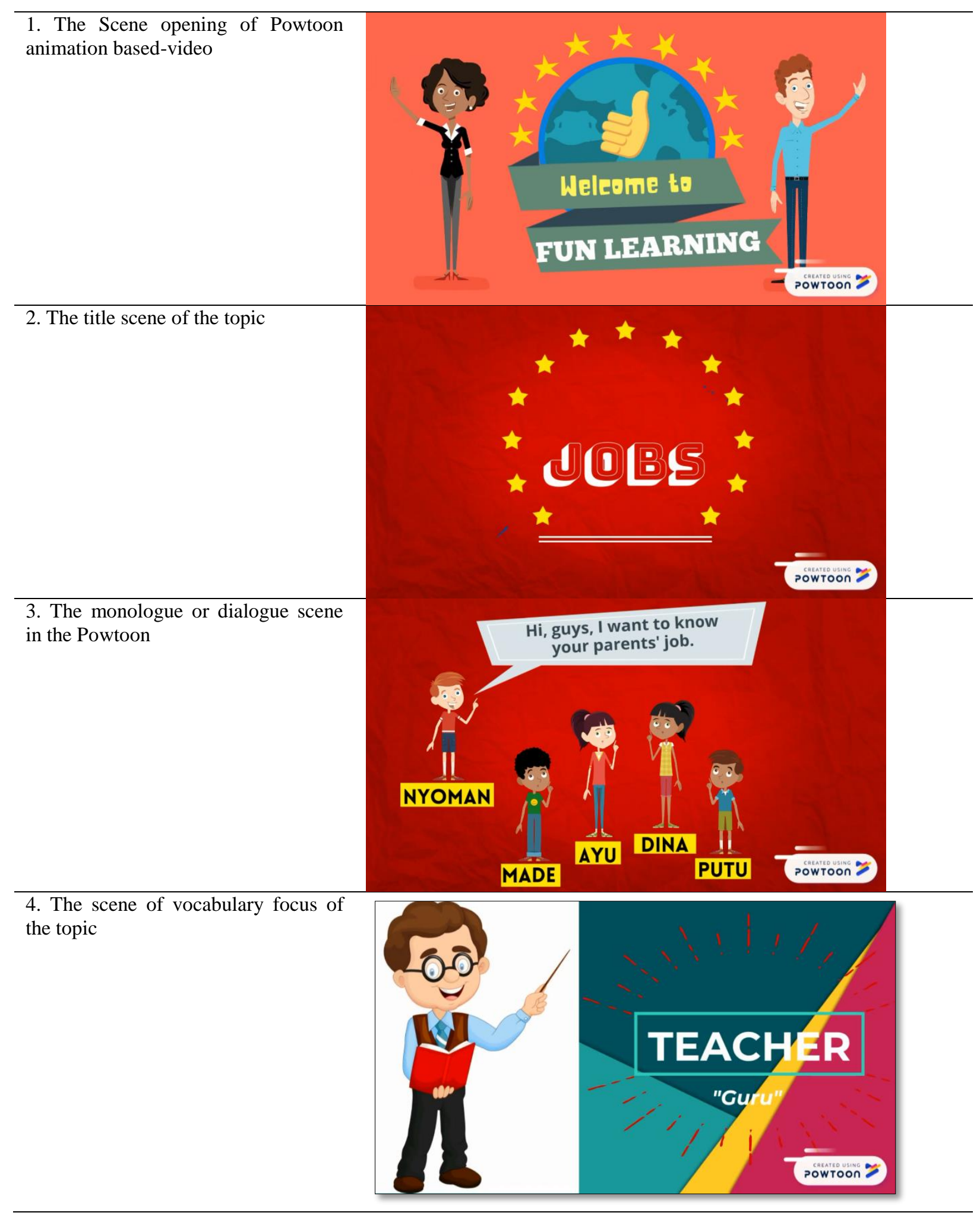


5. The ending video scene of Powtoon animation based-video

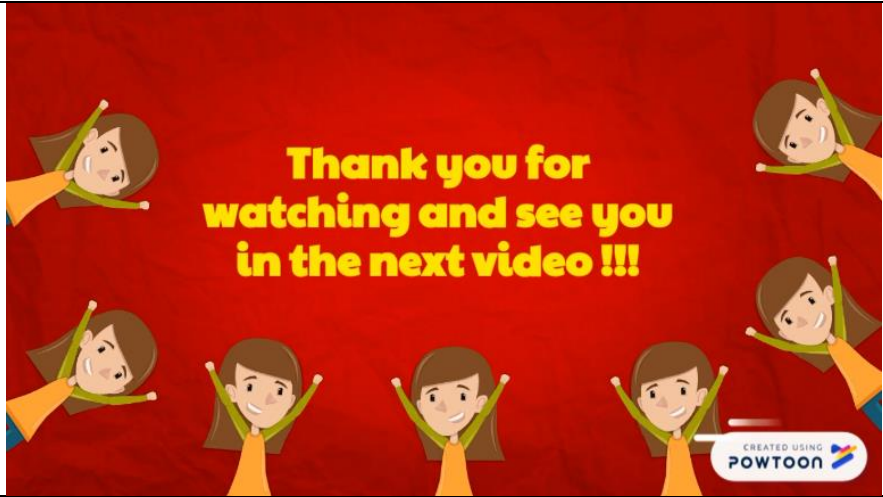

Judged by an expert of media development to know the quality of the media. In the rubric of expert judgement media, there were some point that should be filled, such as the general comments toward the media developed, the strengths of the media that should be defended, the weaknesses of the media what should be minimized, and the score of the media range from 1 until 5 for each aspect. The formula used in determining the quality of the media was same as the expert judgement of material, using Nurkancana and Sunartana (Mahayanti, 2017). Four indicators of a good media that should be given scores by the judge, the first were the graphic of the media, then the technique of media presentation, the audio of the media, and the last indicator is education. All those aspects were divided into 20 statements in order to rating the quality of the media. For the details of expert judgement rubric can be seen in the Table 4.

Table 4. The calculation in Rating the Media

\begin{tabular}{ll}
\hline Score & Criteria \\
\hline$X \geq 90$ & Excellent Material \\
$70 \leq X<90$ & Good Material \\
$50 \leq X<70$ & Average Material \\
$30 \leq X<50$ & Below Average Material \\
$X<30$ & Poor Material \\
\hline
\end{tabular}

From the result of rubric expert judgement of media developed, the media rating in Powtoon animation based-video was found that total score was 97 . The score was categorized as excellent media. It can be concluded that the Powtoon animation based-video was excellent.

\section{Discussion}

As it is stated in the findings, the purpose of conducting this research was for developing Powtoon animation based-video as media to teach English for third-grade students of an elementary school in Singaraja. The media was in the form of video of animation which developed based on syllabus analysis, the material consultation and revision by the supervisors, and also media development. Based on the result of questionnaire of the students, they need a supporting media which can make them learning not only inside of the school hours, but also outside the school hours. The media is in the form of ICT such as Powtoon animation based-video which can motivate them in learning. It is supported by a theory of using ICT media (Anggeraini, 2018), state that using a computer as the media trough learning process can make students be more active and creative so that the teacher should know how to provide the technology in teaching process. Based on the teacher's interview, the researcher found that the teacher was already had responsibility to use such kind of media. In the past there was a learning media to teach vocabulary in the form of games but because of the games was developed formed of $\mathrm{CD}$, it was easy damaged the content inside it. Then, the researcher was suggested the teacher to use Powtoon animation based-video to solve this problem because the Powtoon application can be used in online web based application. Powtoon animation based-video is similar with Power Point, Impress or Prezi (Charbel \& Ismail, 2018).

There was some revision process during the development of the media from the expert of materials and expert of media. In this case, the researcher wants to create a good media in order to make the students enjoy in learning English and support the teaching process of teacher. This relates to a theory of ICT state that ICT in education point of view refers to information and communication technology such as computers, communication facilities, and features that variously support teaching learning and a range of activities in education (Kent, 2014). In doing expert judgement of the materials and media before the revision, the researcher using the formula proposed by Nurkancana \& Sunartana (Mahayanti, 2017). From the expert of material before revision, the first expert judge gives score 58, and the second expert judge gives score 71 . Then, the expert of media 
before revision gives score 89 . In conclusion, it is categorized as good media, but there is some revision needed to improve the quality of the media from some aspects such as grammar revision in the material, and layout of video in media revision. Furthermore, after the revision process has done by the researcher, the first expert judge gives score 71, and the second material expert judge gives score 72. Then, the media expert judge gives score 96 which is categorized as excellent media. Overall, from all the judges of the media, Powtoon animation basedvideo media can be categorized as a good media which ready to tried out in the field.

Although, this research about the developing Powtoon animation based-video as media to teach English for third grade students of elementary school was not perfect. Apart of the strength of this media, this media also had weaknesses. The strength of this media of this media was it was simply, easy-to-use and it helpful for the teacher, it can be seen from the evaluation of the teacher said that, the media is really helpful in teaching process. Then, this media also can improve the students' motivation in learning English, it can be seen from the observation check list and the students' answer in questionnaire of evaluation. In the other side, the weakness of the media was the recording of the sound in the video still in the medium quality but it still useful to hear by the students in the class.

\section{Conclusion and Suggestions}

This research belongs to research and development which was aimed to develop Powtoon animation based-video as media to teach English for third-grade students of an elementary school in Singaraja. In this study, there are six topics were developed into Powtoon animation based-video. Those were jobs, hobbies, name of days and its activity, name of months and dates, time and activity on Sunday, and room in the house. Each topics consists of minimum four vocabularies included with the pronunciation, the product of this study was designed based on the syllabus analysis, criteria of a good video, and the expert judgement and suggestions. In relation with developed a prototype product named Powtoon animation based-video, after implemented the media in the field, it showed that, the media can be categorized as the media was categorized as a good media which could motivated the students and make them so enthusiastic and motivated in learning English with video. The media are also helpful and easy-to-use for the teacher to teach students in grade three at elementary school.

\section{References}

Baldauf, J. R., Kaplan, R., Kamwangamalu, N., \& Bryant, P. (2012). Current Issues in Language Planning Success of failure of primary second/ foreign language programmes in Asia. what do the data tell us?, $37-41$

Charbel, S., \& Ismail, N. (2018). The Effect of Using Powtoon on Learning English as Foreign Language. International Journal of Current Research, Vol.10.

Mahayanti, N. W. (2017). Developing CALF (Contextual, Attractive, Logical, And Fun) Media to Teach Reading for Young Learners. International Journal of Language and Literature, Vol.1, No2, May.2017. ISSN:2549-4287. Universitas Pendidikan Ganesha.

Piaget, J. (1973). To understand is to invent: the future of education (G. Roberts, Trans). New York: A Division of The VIking Press.

Puspitarini, D. Y., Akhyar, M., \& Djono. (2018). Developing Powtoon-Based Video Learning Media for Five Grade Students of Elementary School. Advances in Social Science, Education and Humanities Research, Volume. 165.

Sadiman, A. (1986). Media Pendidikan Pengertian Pengembangan dan Pemanfaatannya. Jakarta: Pustekom Dikbud dan PT. Raja GrafindoPersada.

Sarkar, N., Ford, W., \& Manzo, C. (2017). Enganging digital natives through social learning. Systematics, cybernetics and informatics, $\mathrm{Vol} 12$.

Sugiyono. (2010). Metode Penelitian Kuantitatif Kualitatif dan R\&D. Bandung: Alfabeta.

Sukmadinata. (2010). Metode Penelitian Pendidikan. Bandung: PT. Remaja Rosdakarya. 